\title{
The Need for First Aid Awareness among Candidate Teachers
}

\section{Eğitim Fakültesi Öğrencilleri için İlk Yardım Eğitiminin Gerekliliği}

\author{
Fikret BíLDiK,' İsa KILIÇASLAN,, ' Cumali DOĞRU,, ${ }^{2}$ Ayfer KELEŞ, ${ }^{1}$ Ahmet DEMIRCAN' \\ 'Department of Emergency Medicine, Gazi University, Faculty of Medicine, Ankara, Türkiye \\ ${ }^{2}$ Şişli Etfal Training and Research Hospital, İstanbul, Türkiye
}

\section{SUMMARY}

\section{Objectives}

Students at schools may require first aid due to illness, deterioration in their condition, or accidents. Therefore, educators should know first aid procedures and be able to put them into practice. In this study, the objective was to determine the level of first aid knowledge among students at a Faculty of Education and evaluate the efficacy of the first aid training (FAT) provided to them.

\section{Methods}

This study included 88 students at Gazi University, Faculty of Education (Ankara). All students were provided 20 hours of FAT over a period of three months. Participants completed pre- and post-FAT questionnaires and a final examination.

\section{Results}

Sixty-one percent of participants $(n=54)$ had attended FAT within the previous five years. Average pre- and and post-test scores were $47.89 \pm 11.29$ and $75.28 \pm 12.62$, respectively. There was a significant increase between the average scores $(p<0.001)$. The proportion of correct responses on basic life support issues was also significantly higher after the training. Significantly more participants felt they had sufficient first aid knowledge and skills after the training (58\%) compared to pre-training (8\%) levels $(p<0.001)$.

\section{Conclusions}

First aid knowledge among students at a Faculty of Education was considered to be insufficient. FAT should be standard in educational programs at all teacher training schools and the results show such training needs to be updated regularly.

Key words: Basic life support; first aid; school teachers; students; training.

\section{ÖZET}

Amaç

Öğrenciler okulda mevcut hastalıklarında kötüleşme veya kaza geçirme nedeni ile ilk yardıma gereksinim duyabilirler. Bu nedenle öğretmenlerin ilk yardım girişimlerini bilmesi ve uygulayabilmesi gereklidir. Bu çalışmanın amacı, öğretmen adayı olan eğitim fakültesi öğrencilerinin ilk yardım bilgi düzeyini ve verilen ilk yardım eğitiminin etkinliğini saptamaktır.

\section{Gereç ve Yöntem}

Bu çalışmaya, 88 Gazi Üniversitesi Eğitim Fakültesi (Ankara) öğrencisi katıldı. Öğrencilere üç aylık dönem içinde 20 saat ilk yardım eğitimi verildi. Eğitim öncesi ve sonrası 20 soruluk ilk yardım bilgileri içeren sınav ve ilk yardım eğitimi ile ilgili anket düzenlendi.

\section{Bulgular}

Bu öğrencilerden 54'ü (\%61.4) son 5 yıl içinde ilk yardım eğitimi almıştı. Ön test not ortalaması $47.89 \pm 11.28$, son test not ortalaması 75.28 \pm 12.62 idi ve aralarında istatistiksel anlamlı artış vardı $(p<0.001)$. Temel yaşam desteği ile ilgili sorulara doğru yanıt verme oranı eğitim sonrası istatistiksel anlamlı olarak artış gösterdi. "Yeterli ilk yardım bilgisi ve becerisine sahip olduğunuzu düşünüyor musunuz?" sorusuna verilen "evet" yanıtı eğitim öncesi \%7.0'den, eğitim sonrası \%58.0'e artış gösterdi $(p<0.001)$.

\section{Sonuç}

Eğitim fakültesi öğrencilerinin ilk yardım bilgilerinin yetersiz olduğu, ögretmen yetiştiren tüm okullarda ilk yardım eğitimi verilmesi ve öğretmenlerin de bilgilerini güncellemesinin gerekli olduğu düşünülmektedir.

Anahtar sözcükler: Temel yaşam desteği; ilk yardım; öğretmen; öğrenci; eğitim. 


\section{Introduction}

First aid is applied to injured or ill persons in any health threatening setting in order to save life, prevent degradation of the situation, or contribute to a treatment process before professional medical care is available. First aid refers to assessments and interventions that can be performed by a bystander (or by the victim) with minimal or no medical equipment. ${ }^{[1]}$

Basic life support (BLS), includes maintaining the safety of the scene where the accident occurs, opening airway, providing mouth-to-mouth ventilation, and external chest compression, and represents the most crucial step in first aid. Cases in which circulation is arrested for more than five minutes, can result in irreversible brain damage or even death. Therefore, in general, life-saving BLS procedures should immediately be applied non-professionals, who happen to be nearby at the time of the incident. ${ }^{[2]}$

Children and teachers spend most of their time within a school environment, which is therefore the most likely setting for incidents (e.g., asthma attacks, epileptic seizures, sports injuries, etc.) that may require first aid procedures. ${ }^{[3]}$ Given that schools may not have any trained healthcare providers on-site, it will be teachers who provide first aid to students. Teachers should therefore be trained in first aid procedures and be able to put them into practice. Teachers should be able to convey basic, accurate, and current first aid knowledge to their students and others in society. Therefore, teachers not only need to receive first aid training (FAT) during their professional development, but should also update their knowledge and skills in the light of recent first aid guidelines.

This study evaluated knowledge of the latest first aid/BLS guidelines among students at Gazi University, Faculty of Education in order to review and determine the efficiency of this particular FAT.

\section{Materials and Methods}

The study methodology involved pre- and post-training questionnaire surveys. The study included first year students at Gazi University, Faculty of Education, Department of Special Education (The Teaching Mentally Handicapped Children Program) between March and June of 2010 and 2011. The participants were provided oral and written information prior to study. The study was approved by the institutional Ethics Committee. Of 105 first year students, the study included 88 who voluntarily agreed to complete questionnaire forms before and after the training and to take tests related to their first aid knowledge.
Participating students were provided 20 hours of FAT by an Assistant Professor at Gazi University, Faculty of Medicine, Department of Emergency Medicine. The course content comprised: 1 hour of definition and aims of first aid; 4 hours of basic life support; 2 hours of first aid in bleeding, shock, methods and practices of bleeding control; 2 hours on injuries and organ ruptures; 1 hour on burns and frost bite; 2 hours on electrical shock and drowning; 2 hours on dislocation, fractures and sprains; 2 hours on methods of rescue and transportation of the injured patients; 2 hours on treating patients with altered levels consciousness; and 2 hours on first aid cases of poisoning. BLS was explained theoretically and students also had the opportunity to put this knowledge into practice through case studies using a manikin. Bleeding control techniques were also demonstrated and applied on a student.

Participants completed a multiple-choice pre-test (20 questions) assessment on their level of knowledge prior to FAT; and a questionnaire on their overall views of first aid and whether they had previously taken a first aid course. Following the training, the same multiple-choice questions were repeated as a post-test and a revised questionnaire form was used to obtain feedback about training. Of the 20 multiple choice questions, 5 were related to BLS. Test scores were evaluated (score range 0-100). Comparisons were made between average pre- and post-training test-scores; and between individuals who had previously received training and those who had not. Answers to the questions related to BLS were also evaluated.

All data were analyzed using SPSS (Version 11.0 for Windows ${ }^{\oplus}$, SPSS Inc., Chicago, USA). Frequency distribution and descriptive criteria were calculated. The KolmogorovSmirnov test was used to test for normality. Mean \pm standard deviation was used to evaluate average test scores. A paired-samples t-test was used to compare average test scores (pre- and post-training) for individuals who had taken the training before, whereas an independent-samples t-test was applied to those with no prior FAT. Questionnaire responses were compared using chi-square, McNemar tests and Fisher exact tests.. A value of $p<0.05$ was taken to indicate statistical significance in all cases.

\section{Results}

Of the 88 participants 43 (48.9\%) were male and 45 (51.1\%) were female. Fifty four (61.4\%) of the students had taken first aid courses within the previous 5 years. Forty one $(75.8 \%)$ stated that they had taken these training during their elementary education, 7 (13.0\%) during primary education, and 6 (11.2\%) during driving courses.

As shown in Figure 1, when the test scores were evalu- 


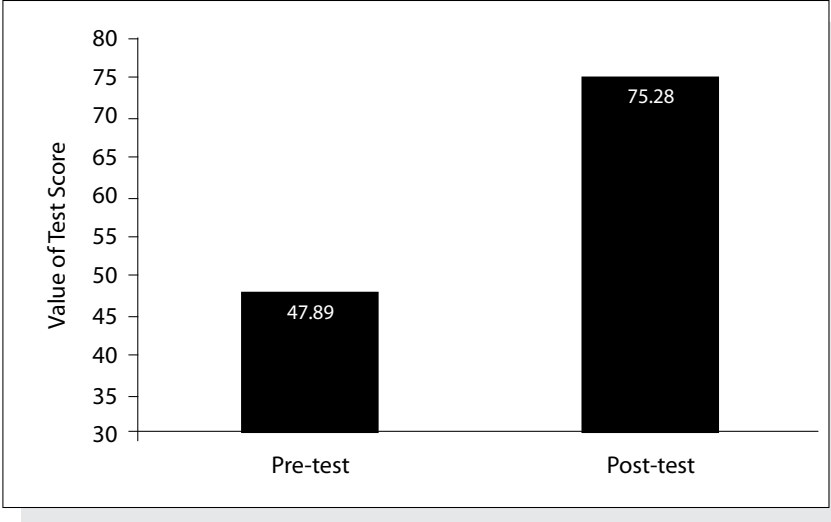

Figure 1. Diagrammatic view of mean value of pre -test and post test scores.

ated out of 100, average pre-test score was found to be $47.89 \pm 11.29$ (minimum 25-, maximum 80 ) and average posttest score was significantly higher, at $75.28 \pm 12.62$ (minimum $45-$, maximum 95$),(p<0.001)$. The average pre-test score among students with prior FAT $(n=54)$ was $49.07 \pm 11.25$, which did not differ significantly $(p=0.220)$ from average score of $46.03 \pm 11.27$ for those $(n=34)$ with no prior FAT. The average post-training test score among participants with prior FAT $(76.29 \pm 12.02)$ was not significantly different $(p=0.346)$ to those with no prior FAT $(73.68 \pm 13.56)$ (Figure

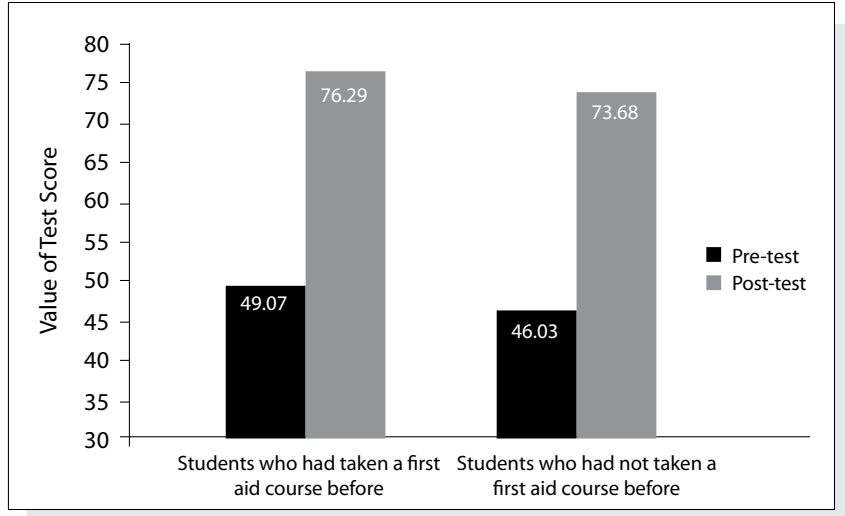

Figure 2. Diagrammatic view of mean value of pre- and post test scores of those who had taken first aid training before and those who had not.

2). Of 5 BLS questions, 3 showed a significant increase in the number of correct answers after the training (Table 1).

Feedback on the training was obtained via a questionnaire form. Prior to training, 7 (8.0\%) of participants responded 'yes' to the question, "Do you think you have enough knowledge and skills when you are faced with someone who needs first aid?" compared with 51 (58.0\%) the training $(p<0.001)$. A majority of the students $(89.8 \%)$ emphasized that FAT should be reiterated sometime during their professional life (Table 2).

Table 1. Pre-test and post-test answers to basic life support questions

\begin{tabular}{|c|c|c|c|c|c|}
\hline \multirow[t]{2}{*}{ Questions } & \multicolumn{2}{|c|}{ Pre-test } & \multicolumn{2}{|c|}{ Final test } & \multirow[b]{2}{*}{$\mathbf{p}$} \\
\hline & $\begin{array}{l}\text { True } \\
\mathrm{n}(\%)\end{array}$ & $\begin{array}{l}\text { False } \\
\mathrm{n}(\%)\end{array}$ & $\begin{array}{l}\text { True } \\
\mathrm{n}(\%)\end{array}$ & $\begin{array}{l}\text { False } \\
\mathrm{n}(\%)\end{array}$ & \\
\hline What is the rate of chest compression/mouth-to-mouth ventilation in an adult? & $10(11.4)$ & $78(88.6)$ & $83(94.3)$ & $5(5.7)$ & $<0.001$ \\
\hline How is mouth-to-mouth ventilation practice evaluated? & $68(77.3)$ & $20(22.7)$ & $77(87.5)$ & $11(12.5)$ & $=0.049$ \\
\hline Where exactly is chest compression applied on the body? & $23(26.3)$ & $65(73.9)$ & $73(83.0)$ & $15(17.0)$ & $<0.001$ \\
\hline What is the leading cause of airway obstruction in an unconscious patient? & $82(93.2)$ & $6(6.8)$ & $88(100)$ & - & $*=0.056$ \\
\hline Which of these actions is primarily performed on a person who has respiratory arrest? & $27(30.7)$ & $61(69.3)$ & 65 (73.9) & $23(26.1)$ & $=0.002$ \\
\hline
\end{tabular}

Chi-Square and *Fisher Exact tests.

Table 2. Answers to feedback questionnaires after the training

\begin{tabular}{|c|c|c|c|}
\hline Questions & $\begin{array}{c}\text { Yes } \\
\text { n (\%) }\end{array}$ & $\begin{array}{c}\text { No } \\
\text { n (\%) }\end{array}$ & $\begin{array}{c}\text { No idea } \\
\text { n (\%) }\end{array}$ \\
\hline Did the first aid training meet your expectations? & 80 (90.9) & $5(5.7)$ & $3(3.4)$ \\
\hline Do you think it is more useful when first aid trainings are provided by emergency physicians? & $85(96.6)$ & $1(1.1)$ & $2(2.3)$ \\
\hline Do you think you have enough first aid knowledge and skills if you ever encounter someone who needs first aid? & $51(58.0)$ & $7(8.0)$ & $30(34.1)$ \\
\hline Did you find the content of the first aid training satisfying? & $74(84.1)$ & $10(11.4)$ & $4(4.5)$ \\
\hline Would you like first aid trainings to reiterate in your professional life? & 79 (89.8) & $4(4.5)$ & $5(5.7)$ \\
\hline
\end{tabular}




\section{Discussion}

Children may encounter life-threatening emergency situations while at school. As they spend most of their time at schools, this is a highly likely setting for illness, deterioration or accidents. ${ }^{[3]}$ Trauma and asphyxia are leading causes of pediatric mortality and, maintaining open airways, supporting ventilation, and controlling bleeding may be life-saving. ${ }^{[4]}$ These first aid techniques should be initiated by teachers who happen to be closest to the student at the time of the incident.

In a study of teachers, $17 \%$ reported witnessing a life-threatening incident involving a student at least once during their career. ${ }^{[5]}$ In a study of 573 school nurses, Olympia et al. ${ }^{[3]}$ reported that $68 \%$ had managed life-threatening incidents requiring emergency medical attention during the previous school year. In the same study, school nurses also indicated that they mostly encountered incidents such as extremity sprains, respiratory disorders, seizures, extremity fractures, head/neck injuries, and lacerations, respectively. They also encountered a lower number of life-threatening cases, such as poisoning, anaphylaxis, airway obstruction, loss of consciousness, and cardiac arrest. Sports injuries also frequently occur at schools. ${ }^{[6]}$ Uner et al. ${ }^{[7]}$ reported the frequency of injuries in school as 10.7\% (among 401 high school students) during the previous three months; in $44.2 \%$ of cases, first aid was applied at the scene.

A study of teachers in Turkey $(n=312)$ found that they lacked sufficient first aid knowledge. ${ }^{[8]}$ Abernethy et al. ${ }^{[6]}$ found that $37 \%$ of physical education teachers did not have up-to-date first aid knowledge. A study conducted in Poland concluded that neither students nor teachers had sufficient first aid knowledge..$^{[9]}$ This supports the importance of our present study on FAT awareness among candidate teachers at the Faculty of Education.

There are no large-scale studies of first aid/BLS knowledge and skills within Turkish society. A study of first aid knowledge among university students reported that their level of first aid was insufficient, as they were only exposed to theoretical FAT. ${ }^{[10]}$ Another study found that university students lacked sufficient knowledge of spinal injuries and interventions, and it was emphasized that practical classes demonstrating first aid techniques would be beneficial for students in other departments besides the health sciences. ${ }^{[11]}$

According to the 2002 First Aid Regulations, published by the Ministry of Health in Turkey, requires that workplaces employ first-aid providers, depending on the number of employees and a minimum of 40 hours of FAT must be provided to those providers. ${ }^{[12]}$ The National Ministry of Education requires that FAT be given together with traffic lessons in primary schools during grades 6 to 8 . Moreover, the Motor Vehicles Regulations include a 12-hour first aid course as part of the process to obtain a driving license. In our study, although $61.4 \%$ of participants indicated that they received FAT within the previous 5 years (either during their primary or secondary education, or during their driving courses), their relatively low pre-test scores indicate that their first aid knowledge was still insufficient and that FAT must be reiterated.

Basic life support represents the most crucial step in first aid and is the foundation for saving lives following sudden cardiac and respiratory arrest. ${ }^{[13]}$ In conformity with the concept of "evidence-based medicine", BLS undergoes continuous progress and changes. During the first year of study, The "Cardiopulmonary Resuscitation (CPR) Guidelines" which was the previous publication in November 2005 by the "International Liaison Committee on Resuscitation" was available at that time. The publication of these revised guideline prompted updates to practical procedures, For instance, according to CPR guidelines published in 2000, the rate of chest compression/mouth-to-mouth ventilation for an adult was $15 / 2$, this was subsequently revised to $30 / 2$ in the 2005 guidelines, and the importance of uninterrupted, high quality chest compressions was emphasized. ${ }^{[2]}$

In another example, an extensive international study reviewed all of data supporting resuscitation and new guidance was recently published, in October 2010. There are significant changes in this guidance related to BLS and first aid. For instance, the order of BLS practice was A (airway), B (breathing), $C$ (circulation) in the previous 2005 guidelines; however in the most recent version, the sequence was revised to C-A-B. In addition, the "Look, Listen, and Feel" approach was removed from the BLS algorithm. ${ }^{[13]}$ Moreover the current guidelines include various changes to some first aid applications, for example control of bleeding. ${ }^{[1]}$ The publication of this latest guidance has also necessitated updating BLS knowledge and skills.

In our study, $88.6 \%$ of students incorrectly answered the pre-test question related to the rate of chest compression/ mouth-to-mouth ventilation in an adult (cited as 30/2 in the 2005 and 2010 guidelines). Seventy-three percent of the students failed to identify the exact position on the chest at which compression should be performed. However, a majority of the students (93.2\%) responded correctly to the question measuring classical knowledge, concerning the most frequent cause of airway obstruction in an unconscious patient (Table 1). These finding indicate that changes introduced in the 2005 and 2010 CPR guidelines, have still not been incorporated by non-healthcare providers; therefore, first aid/BLS training should be regularly updated. Conse- 
quently, there is a clear requirement for continual first aid training and review.

\section{Limitations}

The number of participants is limited, as this particular study includes only the students at Gazi University, Faculty of Education, Department of Special Education ("The Teaching Mentally Handicapped Children" Program). The effect of students' non-attendance during the training hours was not considered. There was insufficient data concerning the quality of students' previous first aid trainings. Furthermore, skill performance and long term retention of this knowledge was not evaluated in the study.

\section{Conclusion}

First aid knowledge among students at the Faculty of Education was considered to be insufficient. FAT should be a standard component of educational programs at all teacher training schools and should also be updated at regular intervals throughout their careers, as part of teachers' continuous professional development.

\section{Acknowledgement}

The authors thank Mustafa IIIhan, MD, for his recommendations on statistical analyses.

\section{Conflict of interest}

None declared.

\section{References}

1. Markenson D, Ferguson JD, Chameides L, Cassan P, Chung KL, Epstein J, et al. Part 17: first aid: 2010 American Heart Association and American Red Cross Guidelines for First Aid. Circulation 2010;122:934-46.

2. International Liaison Committee on Resuscitation. 2005 In- ternational Consensus on Cardiopulmonary Resuscitation and Emergency Cardiovascular Care Science with Treatment Recommendations. Part 2: Adult basic life support. Resuscitation 2005;67:187-201.

3. Olympia RP, Wan E, Avner JR. The preparedness of schools to respond to emergencies in children: a national survey of school nurses. Pediatrics 2005;116:738-45.

4. Eisenburger P, Safar P. Life supporting first aid training of the public--review and recommendations. Resuscitation 1999;41:3-18.

5. Gagliardi M, Neighbors M, Spears C, Byrd S, Snarr J. Emergencies in the school setting: are public school teachers adequately trained to respond? Prehosp Disaster Med 1994;9:222-5.

6. Abernethy L, MacAuley D, McNally O, McCann S. Immediate care of school sport injury. Inj Prev 2003;9:270-3.

7. Uner $\mathrm{S}$, Ozcebe $\mathrm{H}$, Cetik $\mathrm{H}$. Injuries and risk factors among first year students of three high school of different socioeconomic levels: medical education. Turkiye Klinikleri J Med Sci 2009;29:180-8.

8. Başer M, Coban S, Taşci S, Sungur G, Bayat M. Evaluating firstaid knowledge and attitudes of a sample of Turkish primary school teachers. J Emerg Nurs 2007;33:428-32.

9. Sosada K, Zurawiński W, Stepień T, Makarska J, Myrcik D. Evaluation of the knowledge of teachers and high school students in Silesia on the principles of first aid. [Article in Polish] Wiad Lek 2002;55:883-9. [Abstract]

10. Ozcelikay G, Simsek I, Asil E. A Study on the Level of Knowledge About First Aid of the University Students. J Fac Pharm Ankara 1996;25:43-8.

11. Köse S, Yıldırım G, Sabuncu N, Özhan F, Yorulmaz H.The knowledge level of students at Halic University on spinal cord injuries. Turk J Emerg Med 2010;10:15-9.

12. [First Aid Regulations]. Resmi Gazete. 2002;24762.

13. Berg RA, Hemphill R, Abella BS, Aufderheide TP, Cave DM, Hazinski MF, et al. Part 5: adult basic life support: 2010 American Heart Association Guidelines for Cardiopulmonary Resuscitation and Emergency Cardiovascular Care. Circulation 2010;122:685-705. 